CCHE2D بررسى اثر همخرايى و واگرايى در آبخيرهاى جانبى با مدل آزمايشخاهى و مدل رياضى

ييمان حيدرىراد'، اميرعباس كمانبدست'،، محمد حيدرنزاد'، عليرضا مسجدى' و هوشنغ حسونىزاده

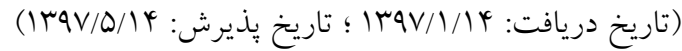

جكيده

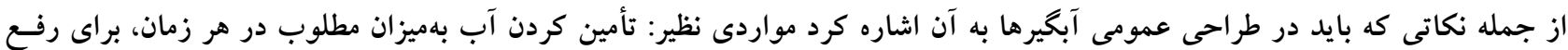

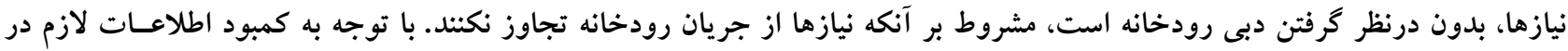

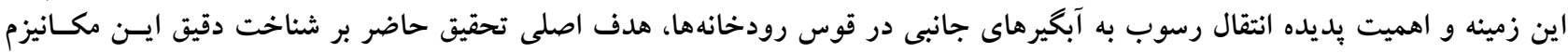

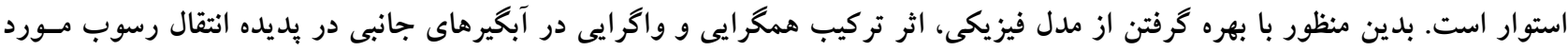

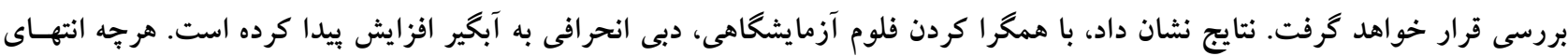

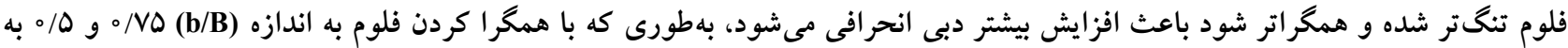

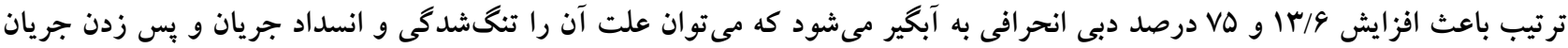

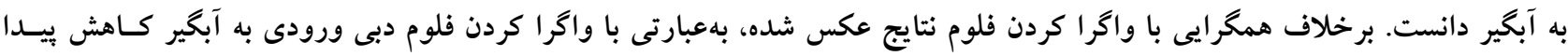

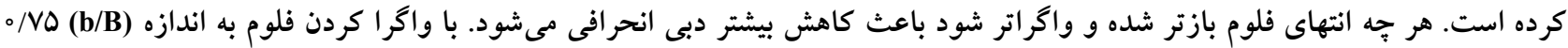

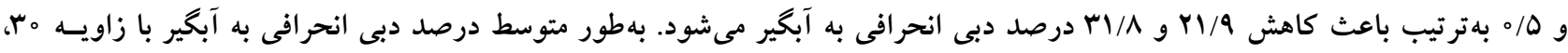

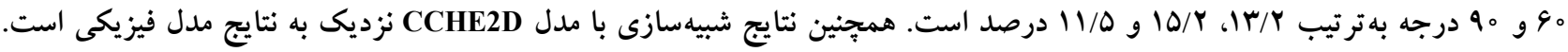

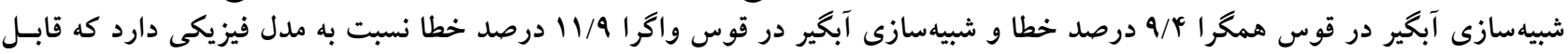
قبول است.

وازههاى كليدى: آبخير، واگرايى، همخرايى، دبى انحرافى، CCHE2D

1 - كروه علوم و مهندسى آب، واحد اهواز ، دانشكاه آزاد اسلامى، اهواز، ايران

r- بازمان آب و برق خوزستان

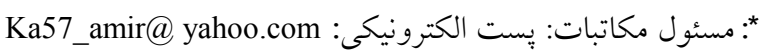




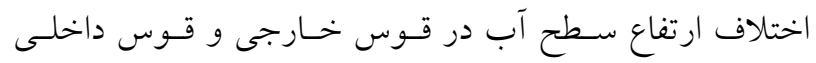

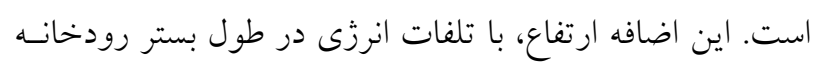

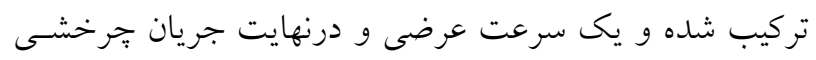
(Recirculating)

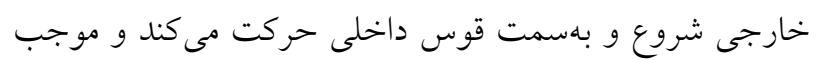

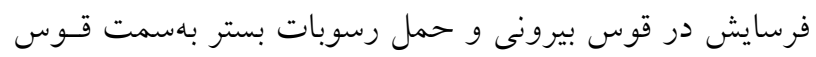

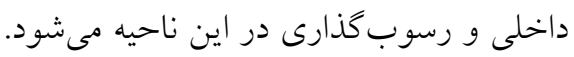

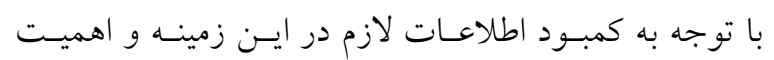

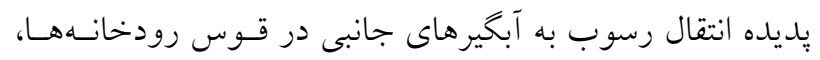
هدف اصلى تحقيق حاضر بر شناخت دقيق اين مكانيزم استوار

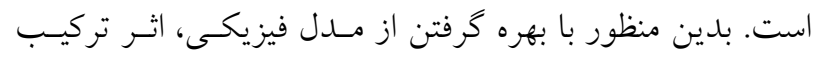

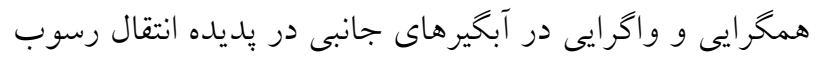
مورد بررسى قرار خواهد كرفت. كمان بدست و همكـاران (9)، در مورد كاربرد آستانه در كنترل رسوب وروددى بـهـ آبخيــر كـار كردهاند. در اين تحقيق مشخص شده اسـت كـه عـرض ناحيـه

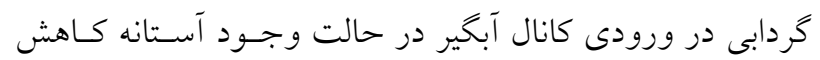

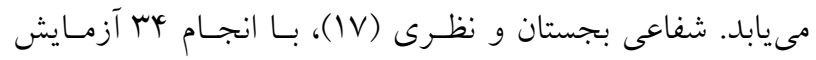

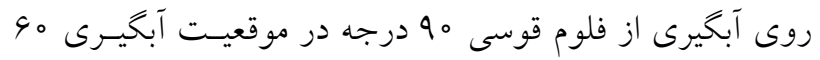

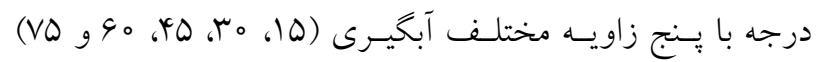

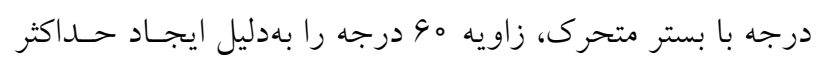

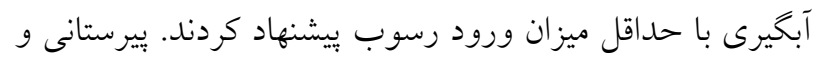

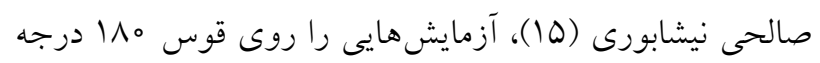

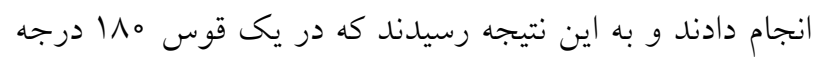

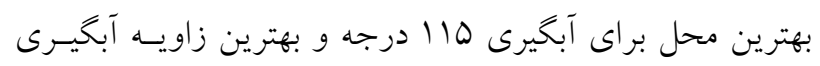

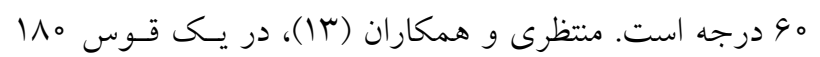
درجه در نسبتهاى آبخيرى كنترل شده زاويه آبخيرى هـا درجه ونه

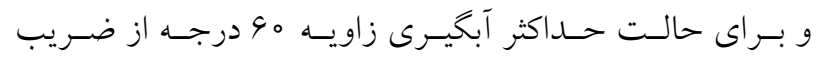

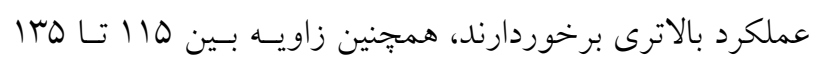

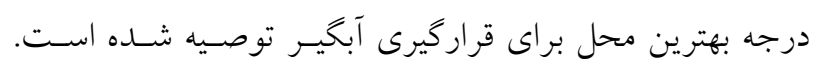

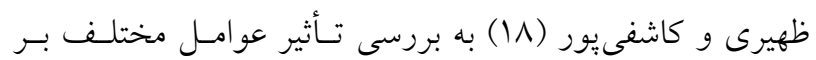

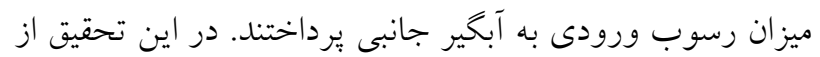

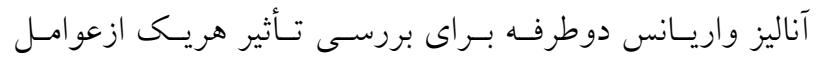

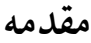

از زمانهاى قديم تاكنون، رودخانهها يكى از منسابع اصسلى تـأمين

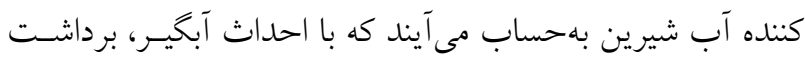

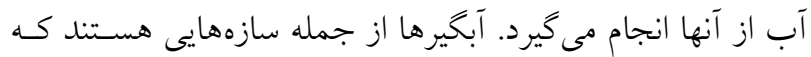

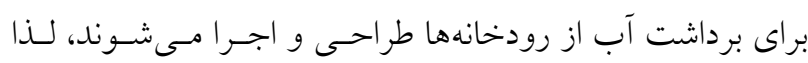

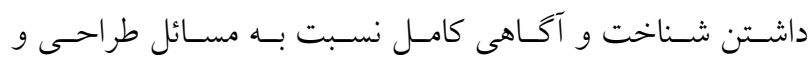

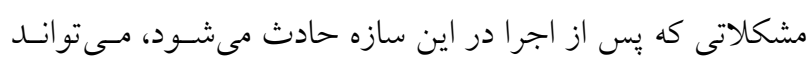

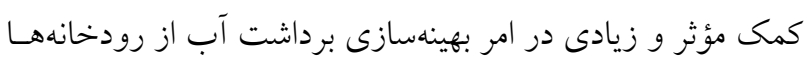

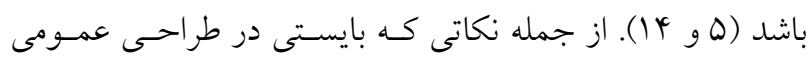

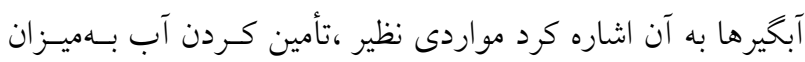

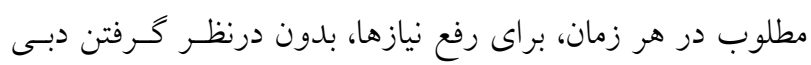

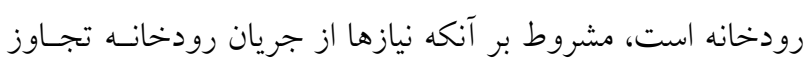

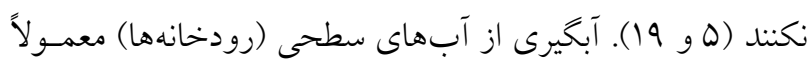
به دو صورت انجام مىشود: روش بمياز و روش ثقلى كـه روش

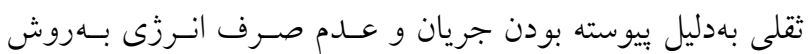
بمياز ترجيح داده مىشود. جنانجه شر ايط تويو گر افى و ميزان نيساز

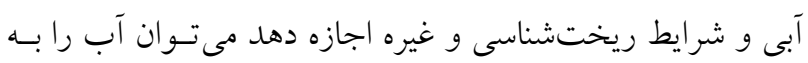

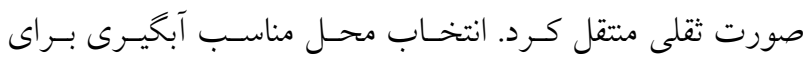

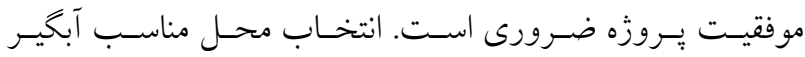

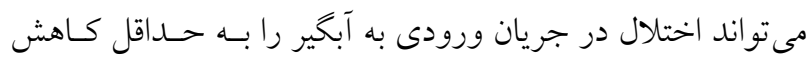

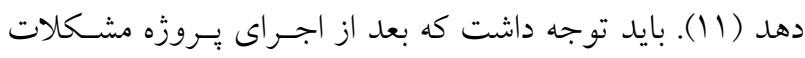

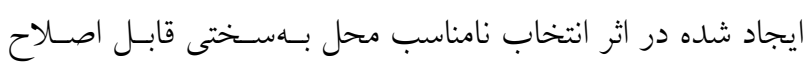

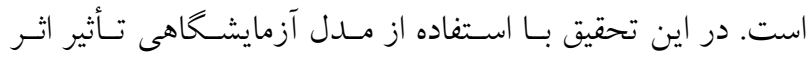

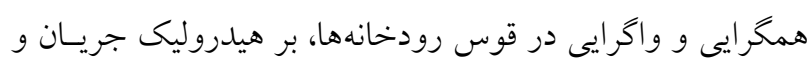

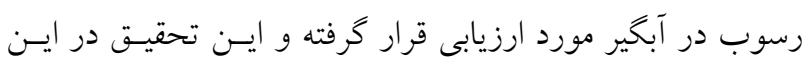

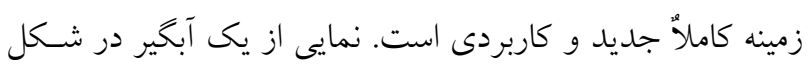
آ آمده است.

ورود جريان به انحناى رودخانه و اعمال نيروى جانب مركز

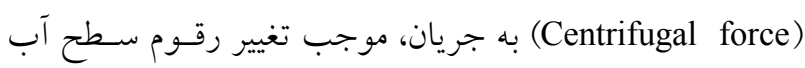

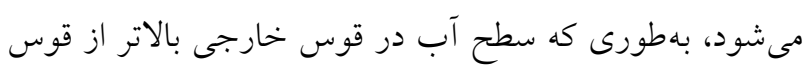

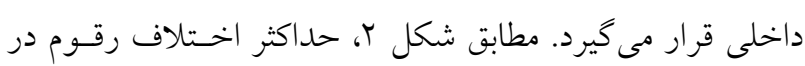

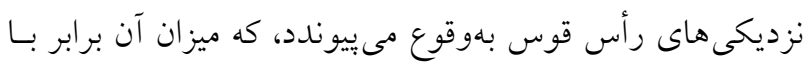


اتصال استفاده كردند. شبيهسازى آنها روى تلاقى هاى همكـف

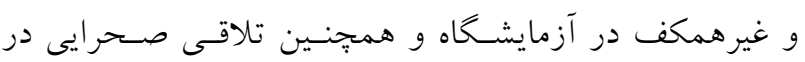

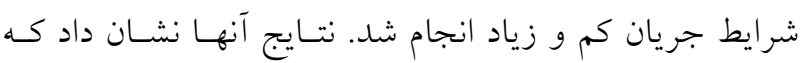

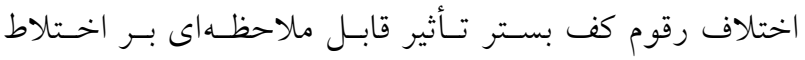

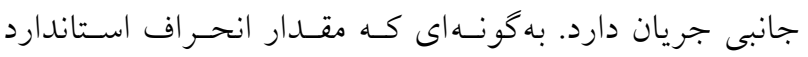

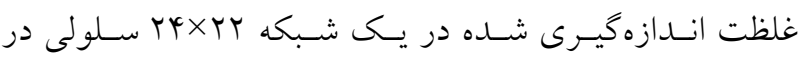
مقاطع عرضى كانال يـاييندسـت تلاقسى غيرهمكـف همــواره كوجكـتر از مقادير متناظر در تلاقسى همكـف اسـت كـهـ ايسن نشان مىدهد اختلاط بيشترى در تلاقى غيرهمكف انجـام مسى

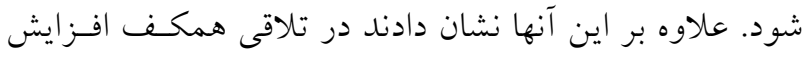
زاويه اتصال از ه9 تا م9 درجه باعث اختلاط سريعتر جريـان مىشود. كمان بدست و همكاران (N)، مطالعهاى را با استفاده از CCHE2D براى بيشبينى رفتـار رسـوبكَذارى در دهانـهـ

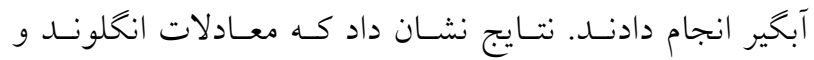
هانسن براى ارائه نتايج انتقال رسوب در بـازه مـورد مطالعه،،

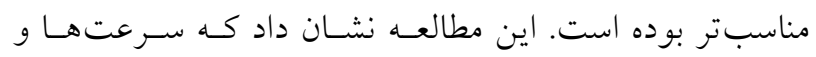

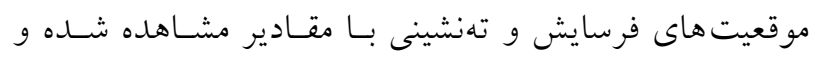

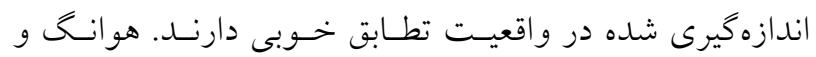

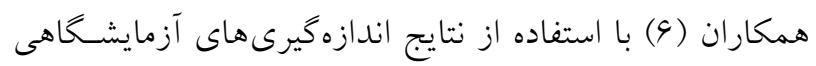

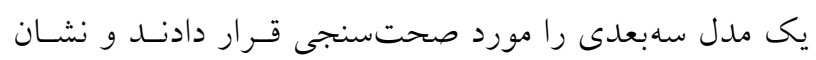

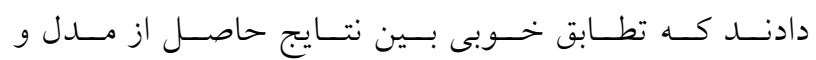

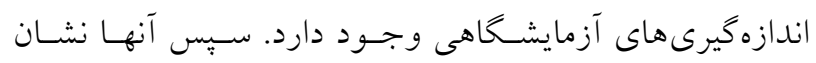
دادند كه با افزايش زاويسه اتصـال از مب تــا هو درجسهـ انــازه

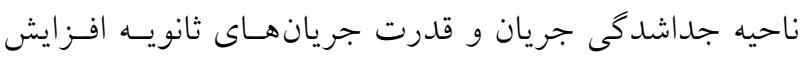

$$
\text { مى يابد. }
$$

\section{مواد وروشها}

مشخصات فلوم ساخته شده و نحوه ساخت آن

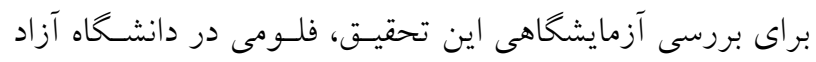

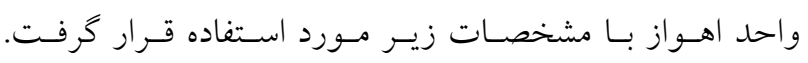

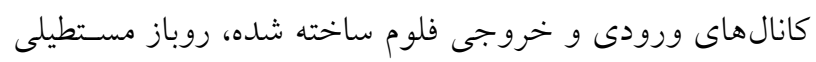
با جداره ورق يلكسى كَلاس اسـت، بـهــورى كـه كـه طـول
موقعيت آبخير، زاويه آبخيرى، ارتفاع آستانه و وجـود بــهـهـاى

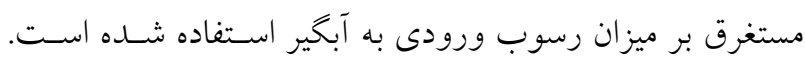

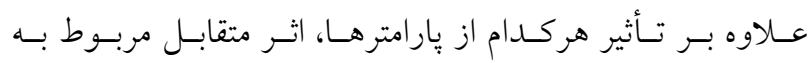

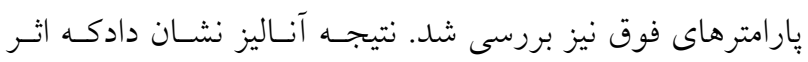

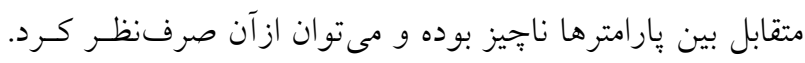

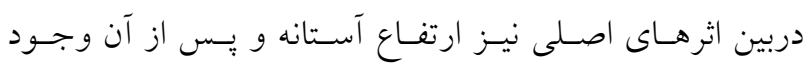

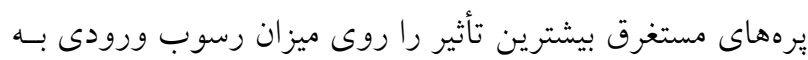

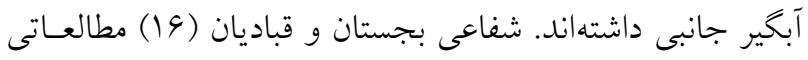
روى مقايسه رسوب معلق ورودى به آبخير جانبى با تغيير زاويه ديواره كانال اصلى از قائم به هष درجه انجام دادند و بيان كردند

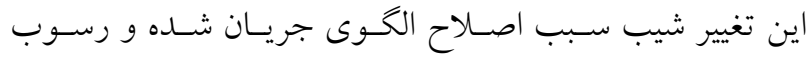
ورودى به آبخير كاهش مىيابد.

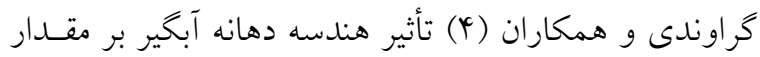
و الكوى رسوب گذارى در آبخير جانبى را بررسى و بيان كردنسـ ايجاد قوس بهينه در ديواره كانال آبخير منجر بــهـ كـاهش مقــدار رسوب ورودى به ميزان حداكثر ه9 درصد خواهد شـد. منـادى

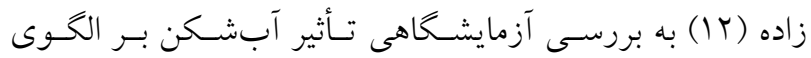

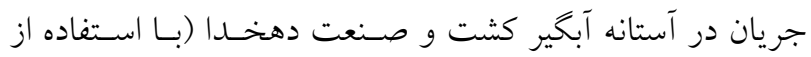

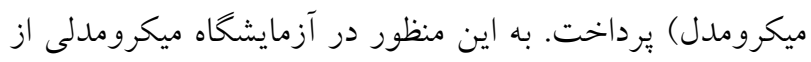

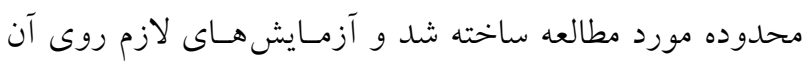

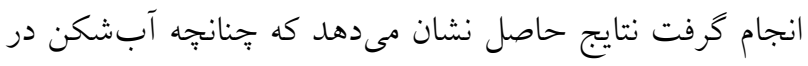

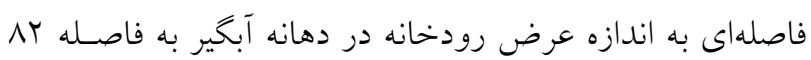

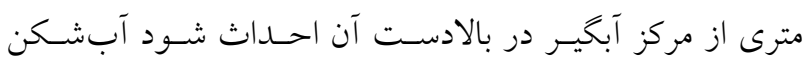

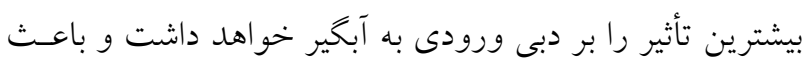

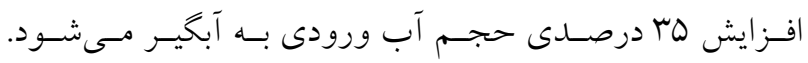
باراكدل و همكاران (1) به بررسى راهكارهاى افـزايش كـاريى

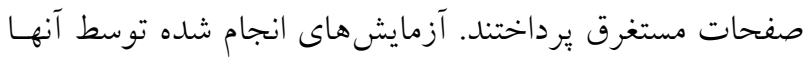

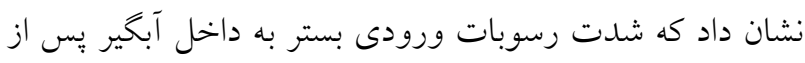

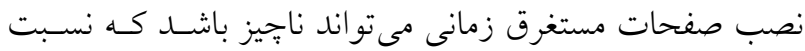

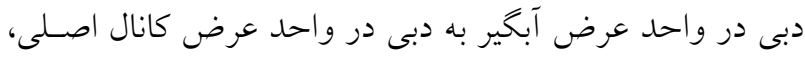

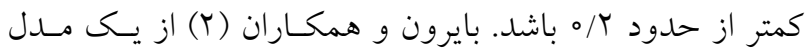
سهبعدى براى بررسى فراينــ اخستلاط جريـان در يـاييندست 


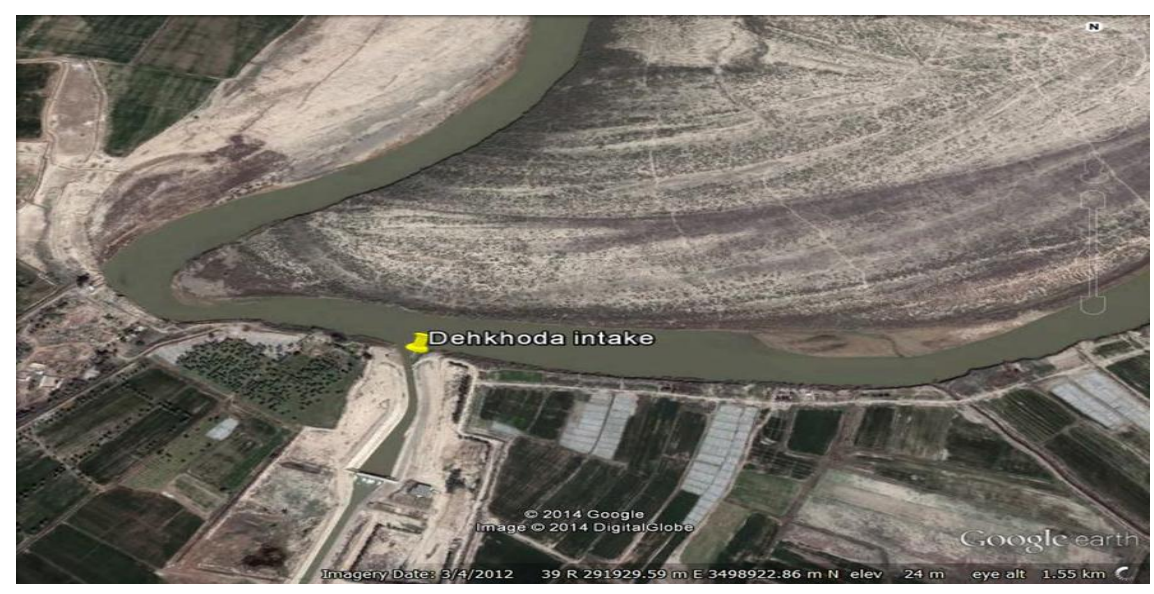

شكل ا. نمايى از يك آبكير

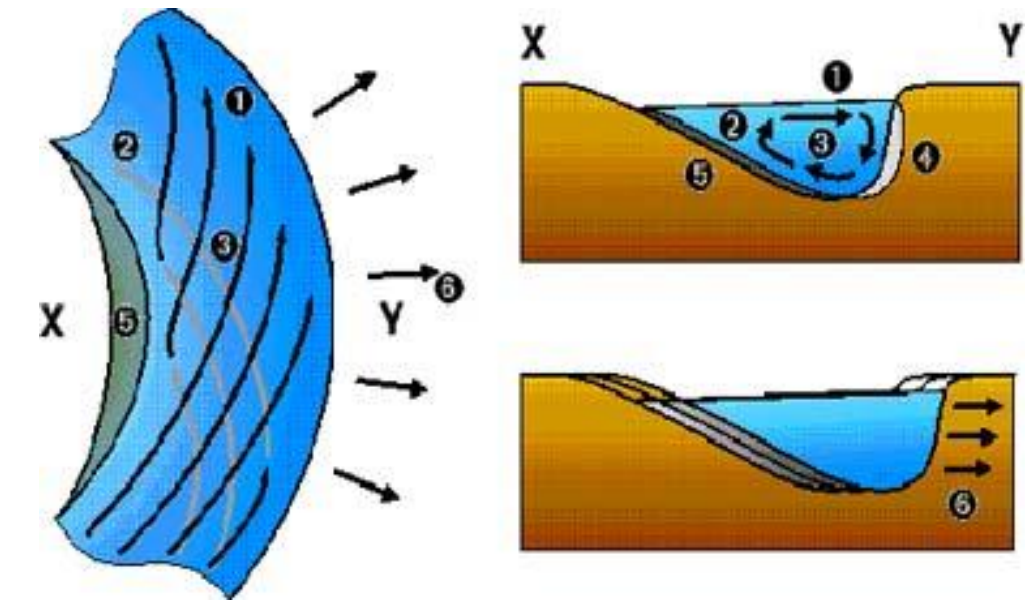

شكل r. روند نمادين جريان در يك خم و تأثير جريان حلزونى بر بستر رودخانه در خم

كانالهاى مستقيم ورودى در ابتداى فلوم و خروجى در انتهاى افقى ساخته شده است (شكل ب).

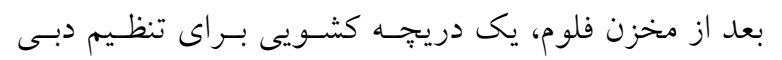
ورودى به فلوم و يكى سرريز مثلثى ه9 درجه براى اندازهيــى لهري

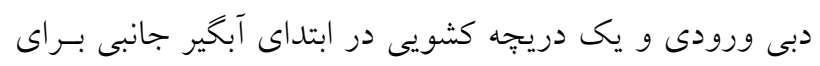

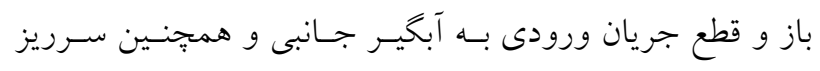

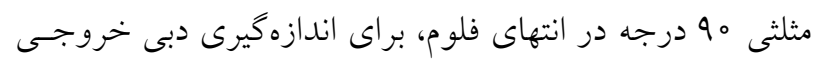

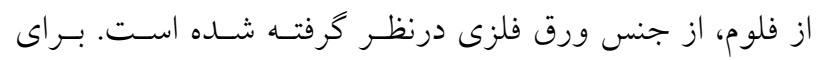

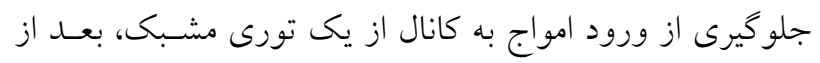
سرريز ابتدايى استفاده شده است (شكل ؤل).

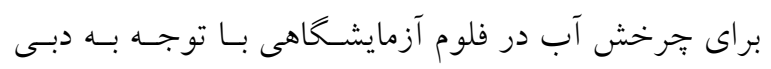

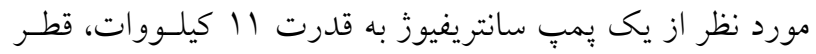

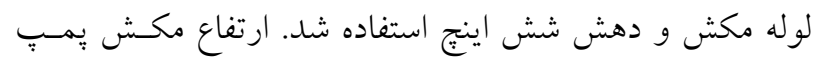

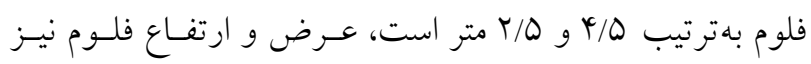

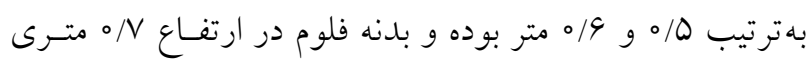
از سطح زمين قـرار دارد. مسـير ورودى مستـقيم (بـراى ايجـاد

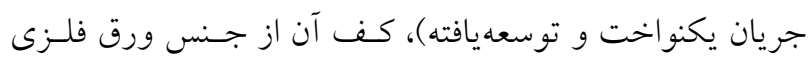

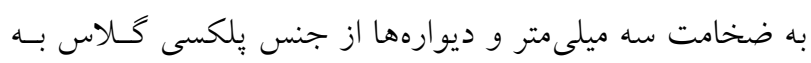

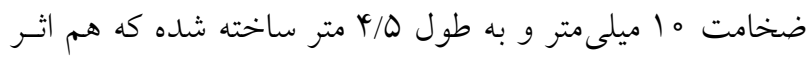

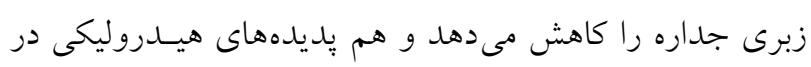

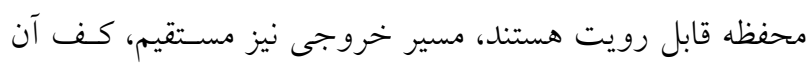

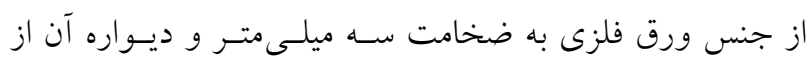

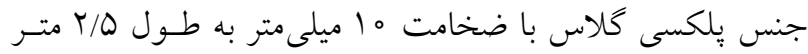

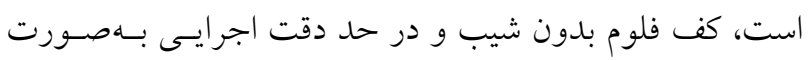




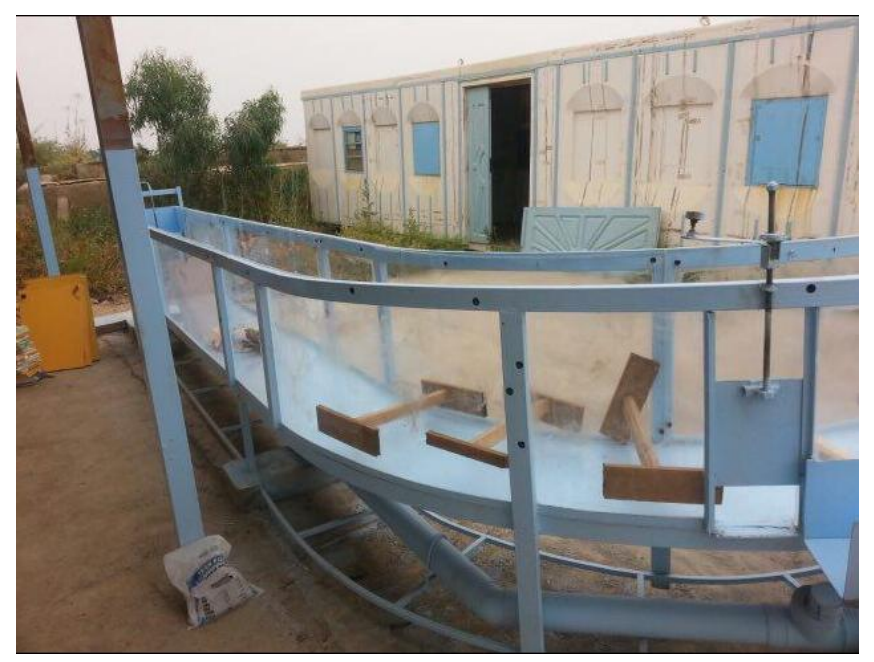

شكل r. نمايى از فلوم
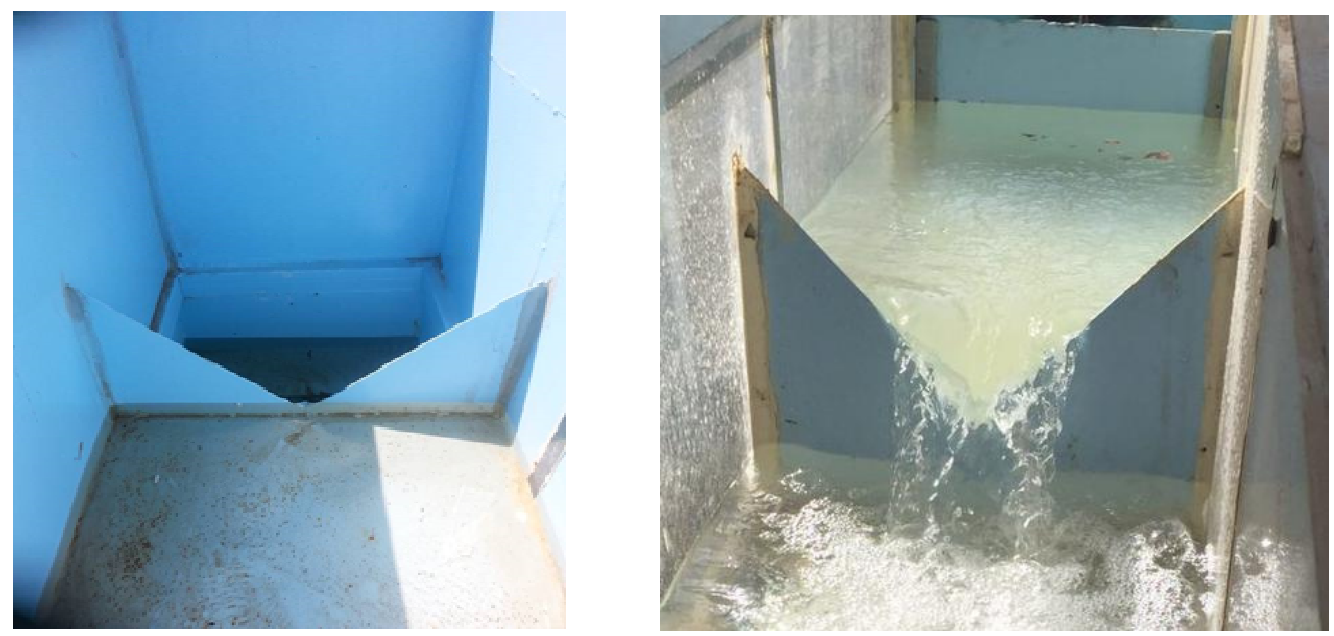

شكل ٪ا. سرريزهاى ورودى و خروجى مثلثى با رأس هq درجه، در ابتدا و انتهاى فلوم

9 9 درجه در اين تحقيق عبارتند از:

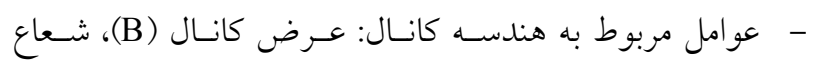

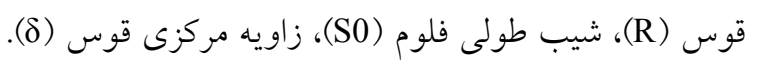

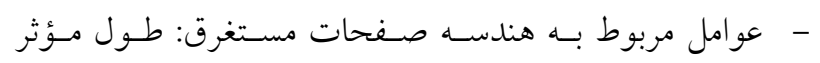

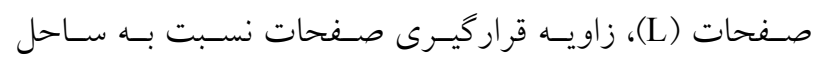

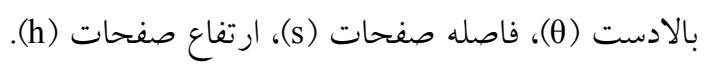

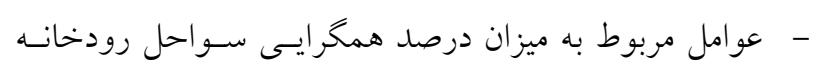
$\mathrm{CR}=(\mathrm{b} / \mathrm{B})$ - عوامل مربوط به ميزان درصد همخر ايسى سـواحل رودخانـه. $\mathrm{DR}=(\mathrm{b} / \mathrm{B})$
تقريبا دو متر و ارتفاع دهش آن حدود مب متـر و حسـاكثر دبسى

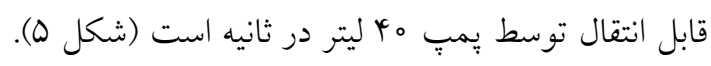

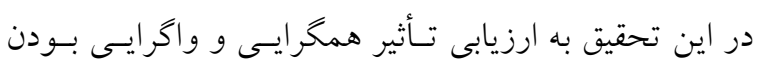
كانال روى هيدروليك جريان در آبخير برداخته شده كه بهمنظور

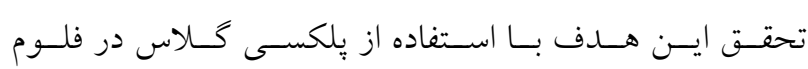

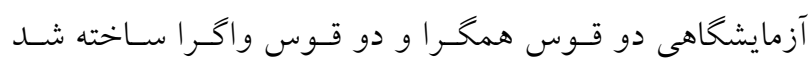

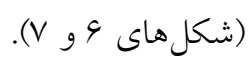

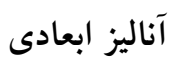
عوامل مهم در ميزان رسوب ورودى به آبخيـر جـانبى در قـوس إنس 


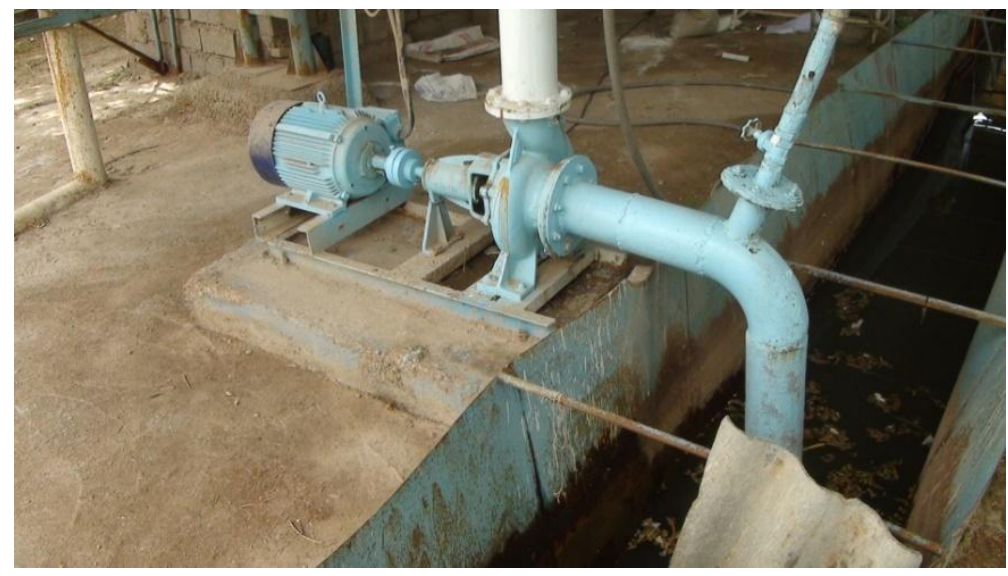

شكل ه. بِمبٍ سانتر يفيوز
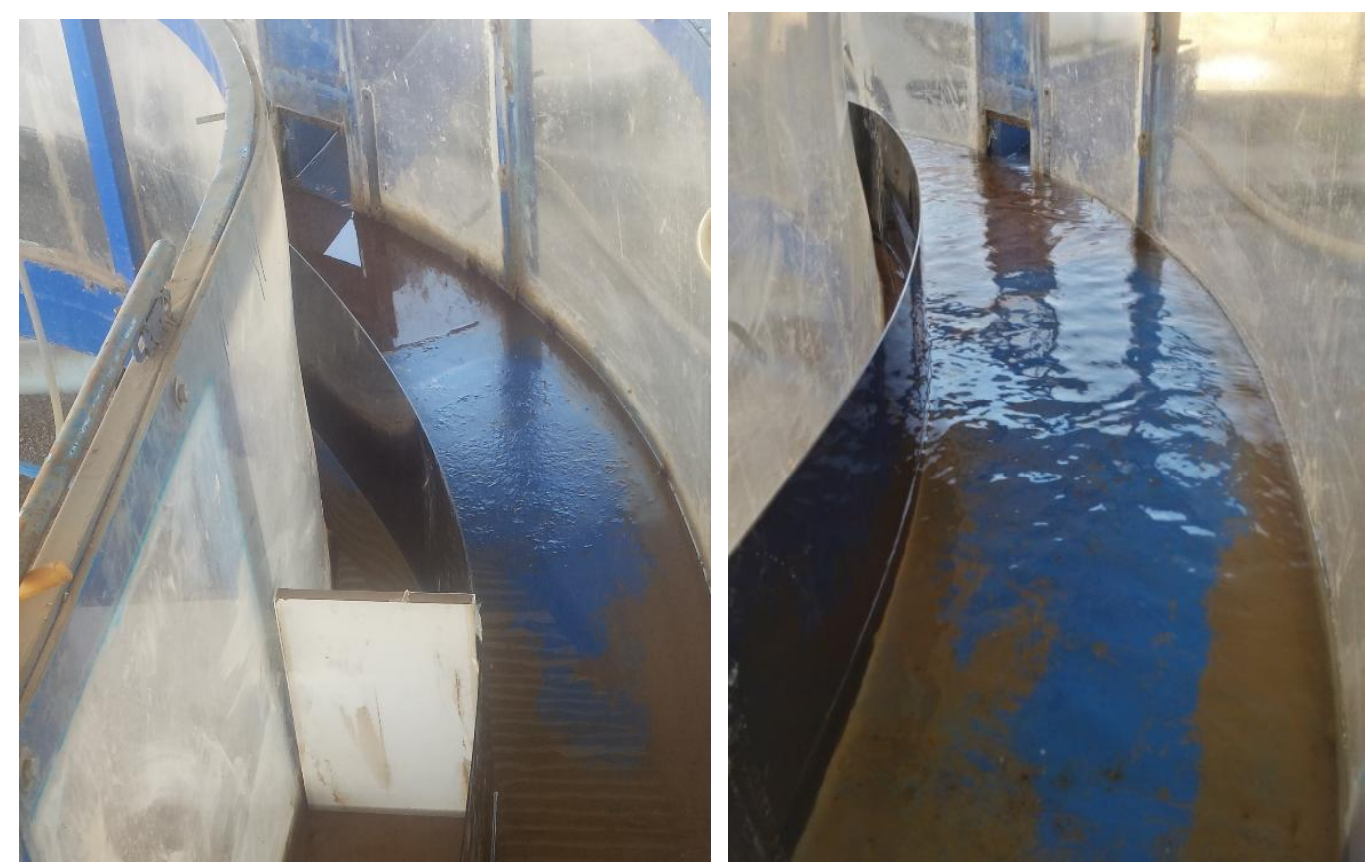

شكل 9. قوس همخرا و واكراى ساخته شده

مورد نظر روابط بىبعد بهصورت زير بهدست مى ينند: $\mathrm{f}\left(\mathrm{CR}, \mathrm{DR}, \theta, \mathrm{F}_{\mathrm{r}}\right)=0$

متغيرهاى آزمايشها در جدول آمآمه است.

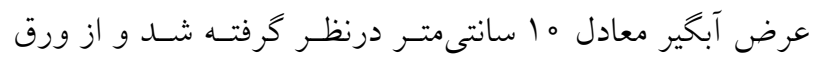
فلزى اسكلت آن ساخته شد.

\section{مدل رياضى CCHE2D}

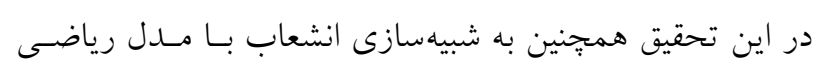

خصوصيات مربوط به شرايط هيدروليكى جريان: دبى جريان در

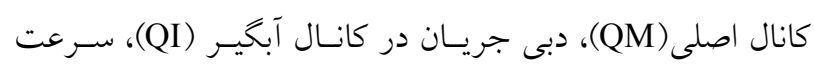

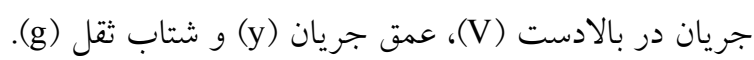

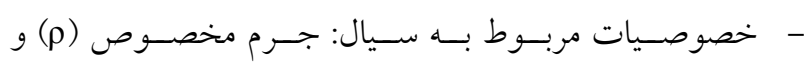
ويسكوزيته ديناميكى (ر) f(B, R, S0, $\delta$, L, $\theta$, s, h, CR, QM, QI, V, y, g, d ${ }_{50}$, S, ds, $\left.\rho, \mu\right)=0$ با استفاده از تئورى باكينخهام و ثابت فـرض كـردن يارامترهـاى 

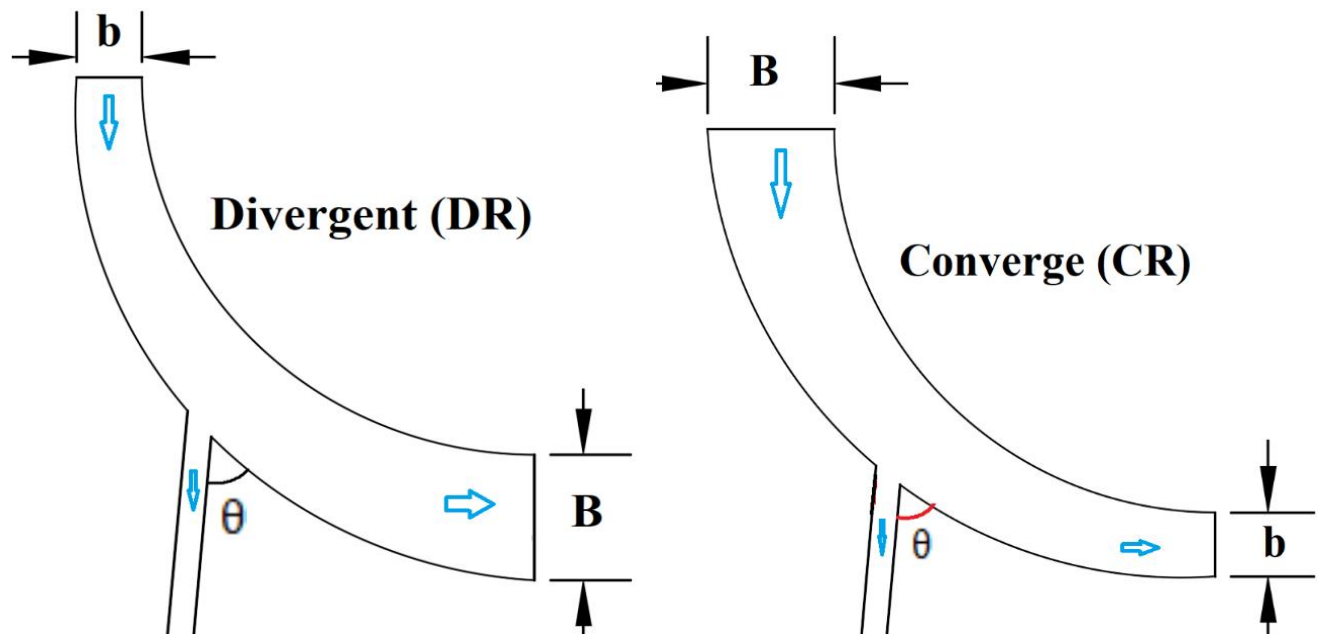

شكل V. نمادين فلوم همكرا و واكرا

جدول ا. متغيرهاى آزمايش

\begin{tabular}{|c|c|c|c|c|}
\hline همخرايى (b/B) (CR) & واخر ايى (b/B) (DR) & 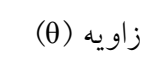 & (Fr) & آزمايش ها شاهد \\
\hline$\circ / \Delta, \circ / V \Delta$ & $\circ / \Delta, \circ / V Q$ & $\mu_{0}, 90.90$ & g و g و و و & 10 \\
\hline
\end{tabular}

رفتـهـ در مــد CCHE2D-GUI را بــر اسـاس روش عـددى المـان محسدود (Finite Element) ممكـن مسىسـازد. مــدل CبـHE2D-GUI كه شرايط جريان در اين مــل بـهــورت غيرمانـدكار اسـت

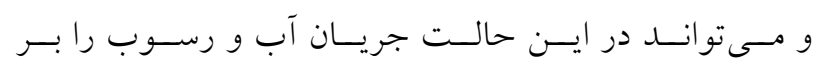

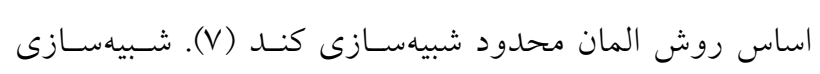

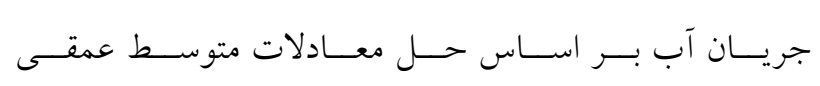
ناوير - اسـتو كس اسـت. تــش برشى مـتلاطم بـا اسـتفاده از

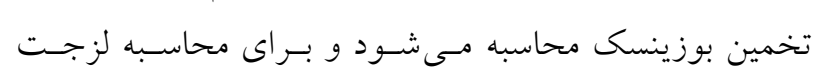

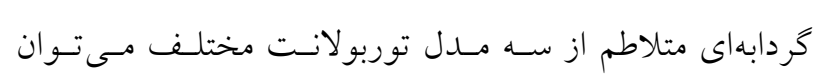

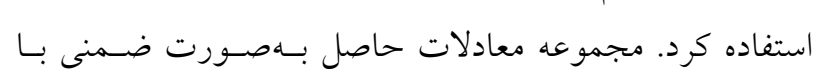

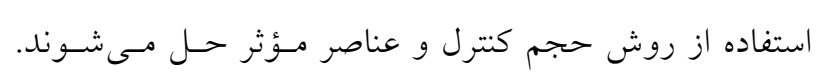

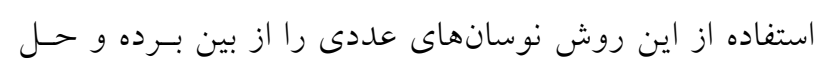

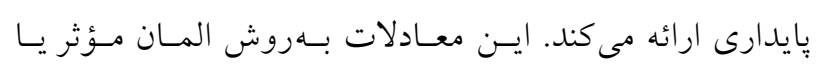
تفاضل هاى نمايى حل مىشوند (r).
نيز يرداخته شد كه در ادامه به معرفى اين نرمافزار و

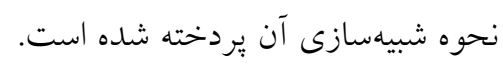
مــل CCHE2D در ســال $199 \mathrm{~V}$ در مركــز بــين المللـى

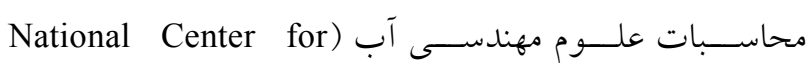
Computational Hydroscience and Engineering توسط وانگ، سام و جيا تحت نظر دانشـاه مسى (NCCHE) سىسىيى آمريكا تهيه شد. در ساليان اخير اين مدل بهتــدريج

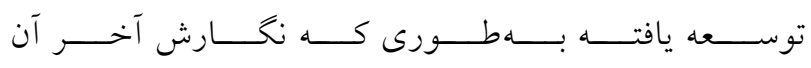
(CCHE2D 3.2) از قابليت هاى زيادى در زمينـه شـبيهسـازى (CHEـ آب و رسوب برخوردار است. كدهاى اين برنامه با استفاده از زبان برنامهنويسى فرترن ه9 نوشته شده است. بهطور كلى اين

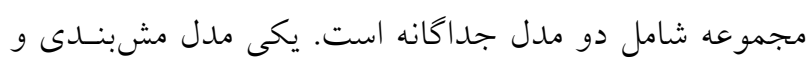
ديخرى مدل CCHE2D-GUI. مدل مشبندى با ايجاد قابليـت

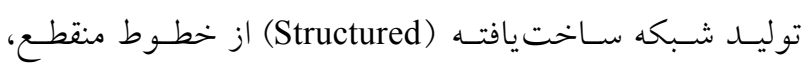
محيطى ايجاد مى كند كه حل معـادلات آب و رسـوب بـهــار 

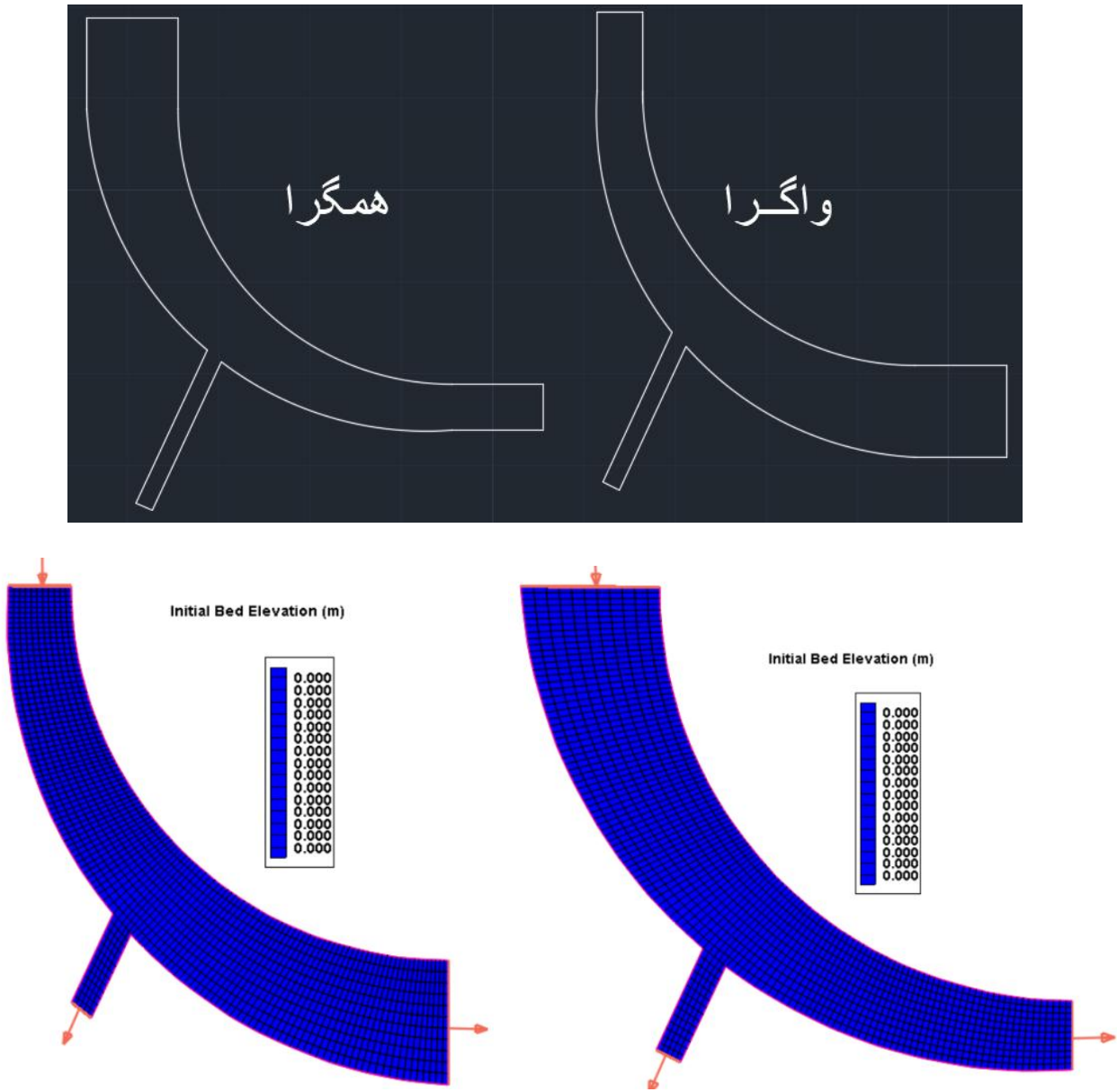

شكل ^ـ نمونه طراحى شده در نرمافزار Auto Cad و شبكه Mesh فلوم با قالببندى geo

جريان شامل رقوم بستر اوليه، تراز سطحح آب اوليـه و زبـرى اوليـه

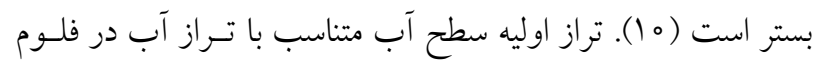

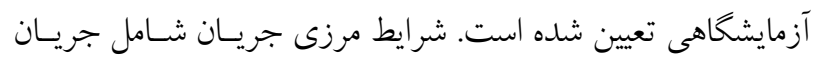

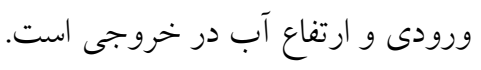

نتايج

نتايج در اين تحقيق شامل بررسى تأثير عدد فرود، تغيــر انــازه

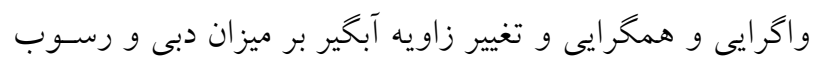

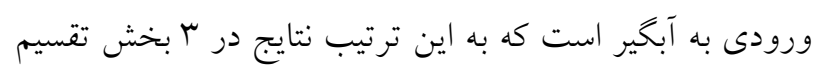

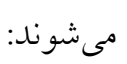

$$
\text { ا - اثر واخرايى و همخر ايى بر آبخير }
$$

r- اثر زاويه آبخير

r- بر بر نقى نتايج شبيهسازى با نرمافزار CCHE2D
تهيه Mesh بر اساس ديتابيس فراهم شده از دادههاى تويوگر افى

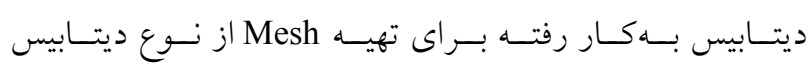

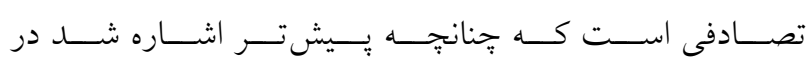

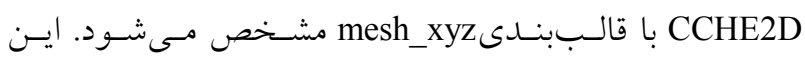

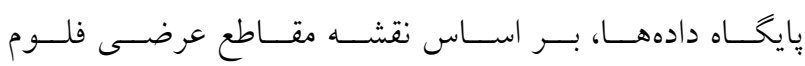

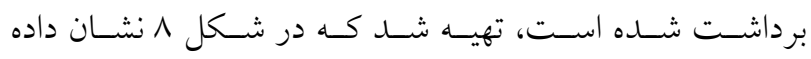
شده است.

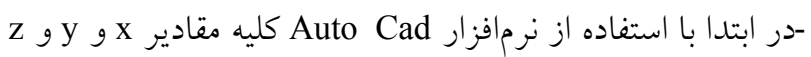

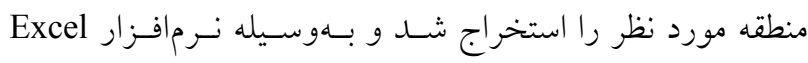
تبديل به فرمت Mesh_xyz* شد كه با مـشبنـدى در شـكل مردمر نشان داده شده است.

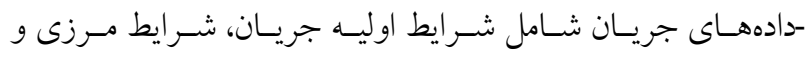
بارامترهاى جريان در مدل CCHE2D هستند. دادهاى شرايط اوليه 


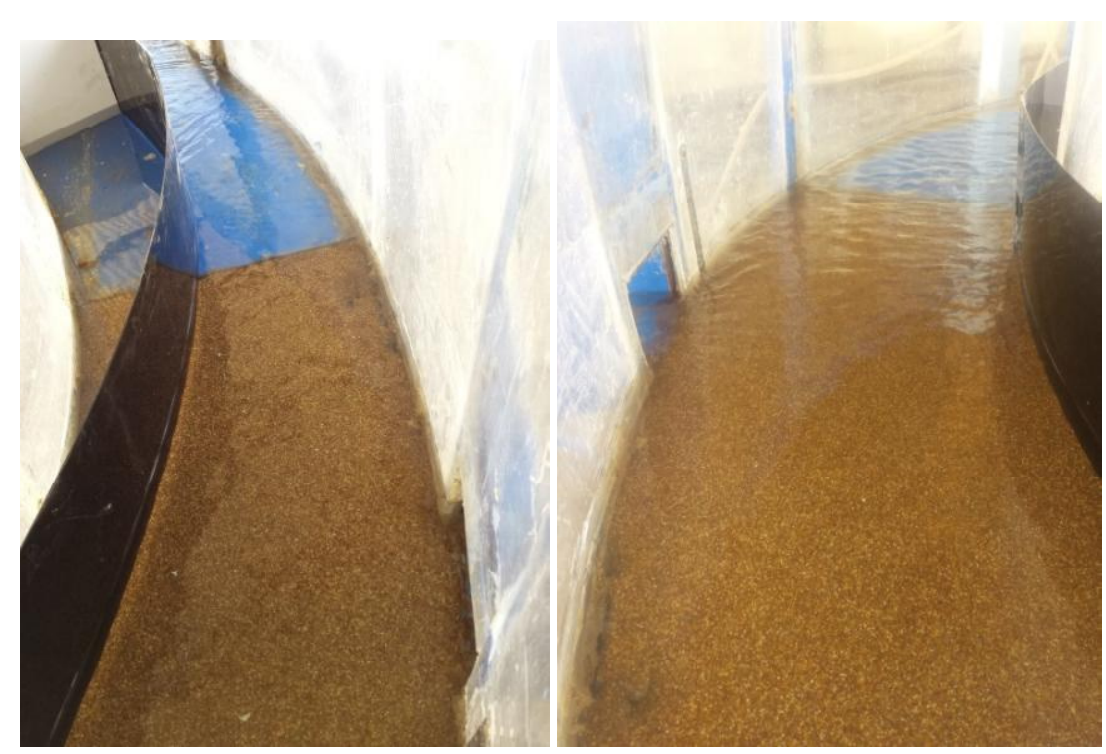

شكل 9. تصاويرى از آزمايشها

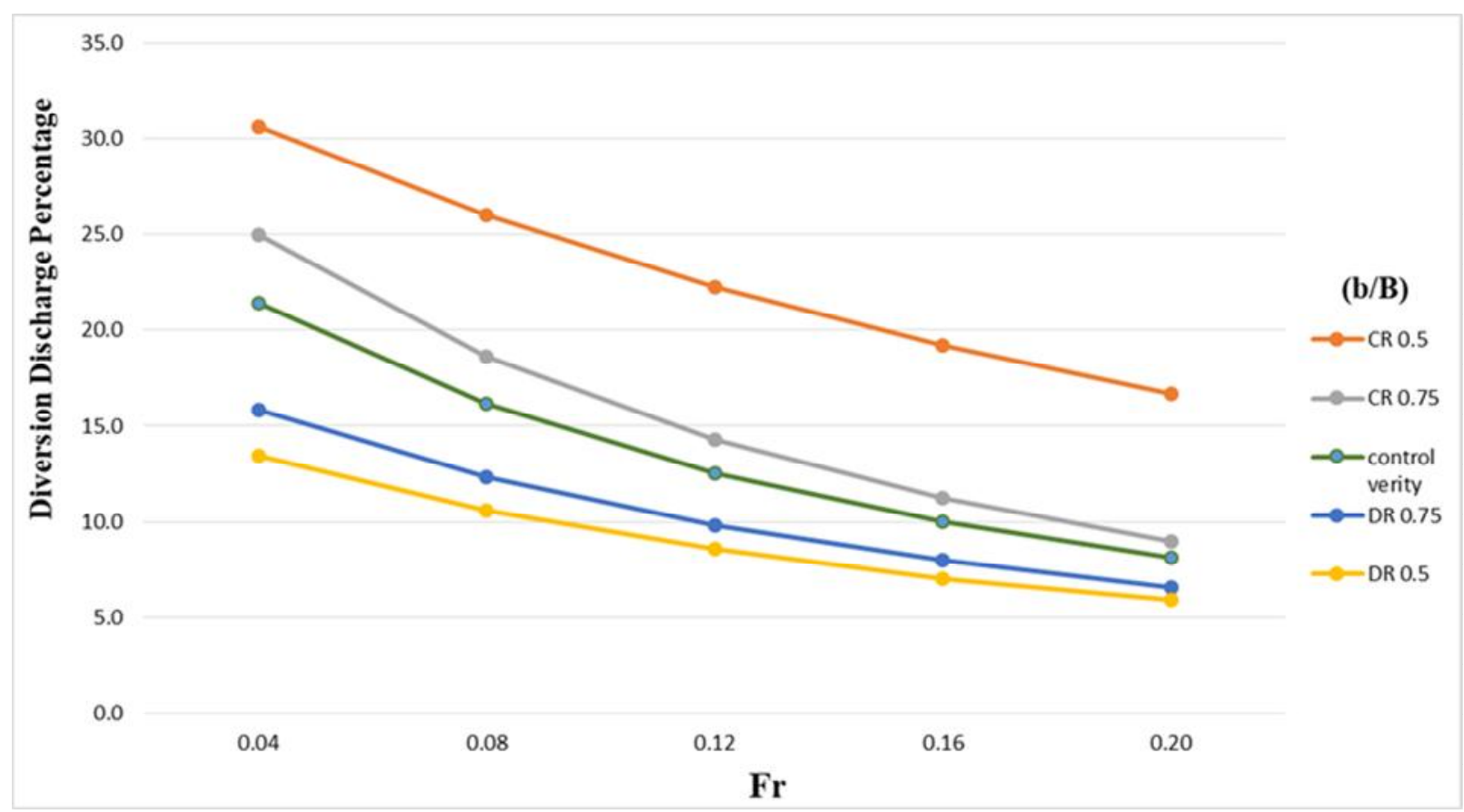

شكل ه ا. نمودار بررسى اثر همخرايى و واگرايى بر دبى انحرافى به آبكير (رنكى در نسخه الكترونيكى)

بررسى تأثير واخرايى و همخرايى بر آبخير برداخته شده است. در شكل 9 تصاويرى از آزمايشها نشان داده شده است.

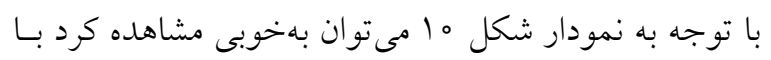

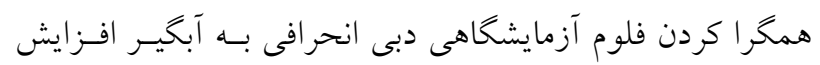
ا- بر بـ اثر واترايى و همخرايى بر آبخير

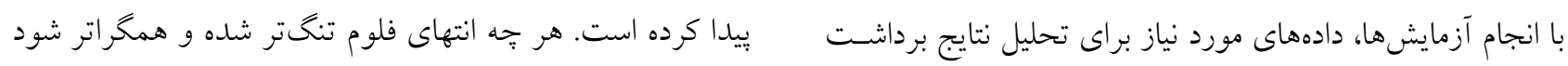

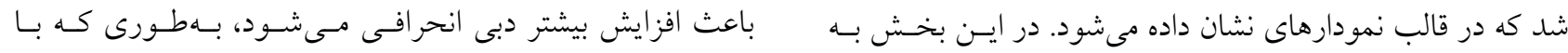




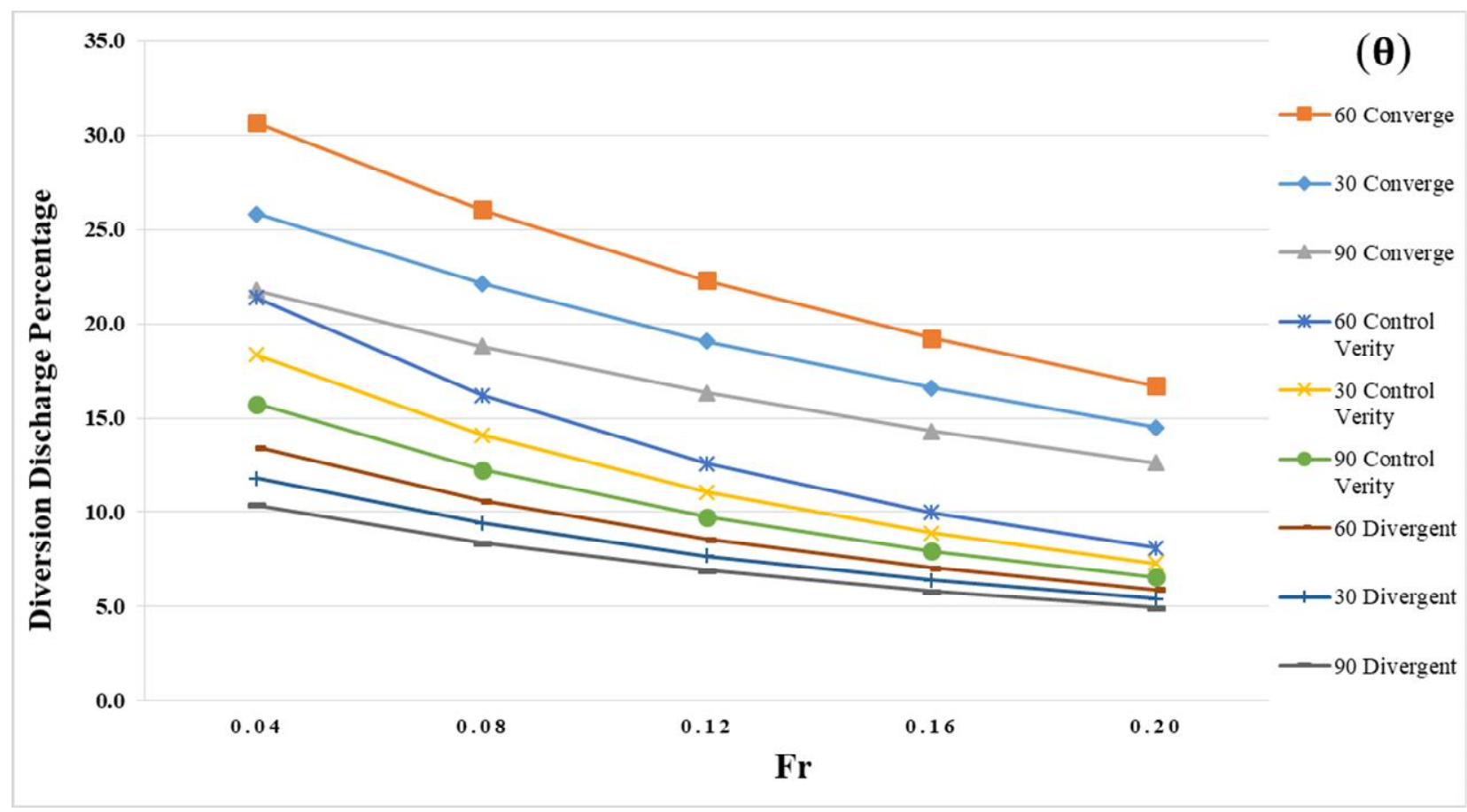

شكل 1لا.نمودار تأثير زاويه آبخير بر دبى انحرافى به آبخير (رنكى در نسخه الكترونيكى)

با توجه به نمودار شكل لا مىتوان بـه خـوبى مشـاهده

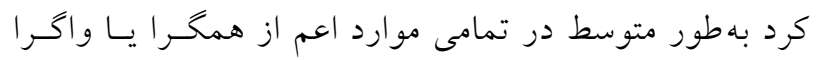

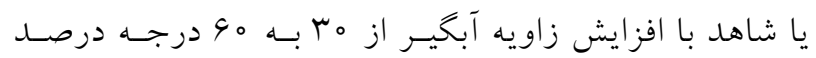

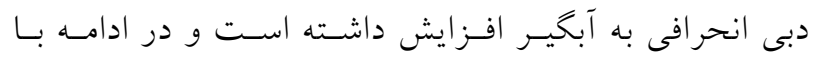

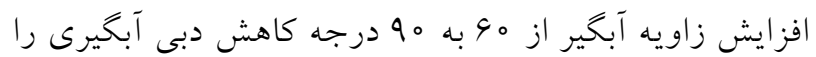
شاهد هستيم. بهطور متوسط درصد دبى انحرافى به آبخير بـا بـا

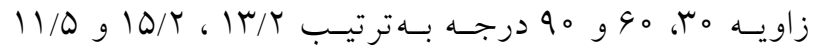
د مرصد است.

r- بررسى نتايج شبيهسازى با نرمافزار CCHE2D

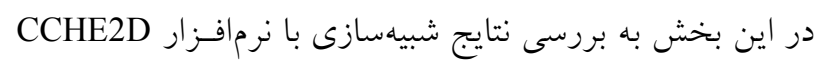

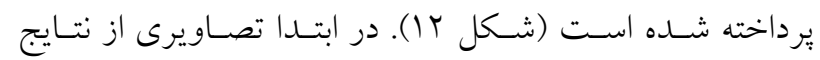

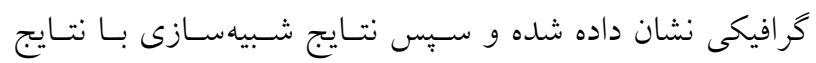
آزمايشگاهى در قالب نمودار مقايسه مىشود.

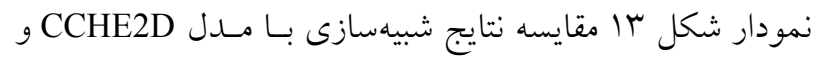

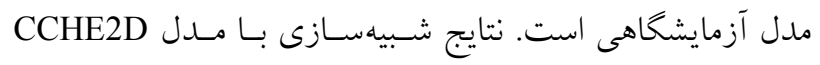

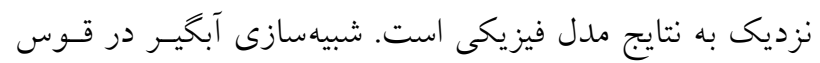

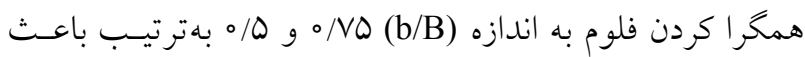

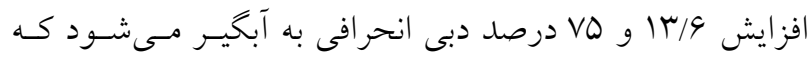

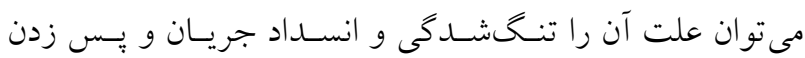
جريان به آبخير دانست. برخلاف همخر ايى با واخرا كـردن فلـوم

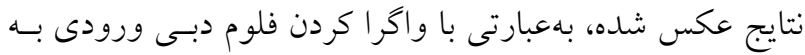
آبخير كاهش بيدا كرده است. هر جهه انتهاى فلوم باز تـر شـده و

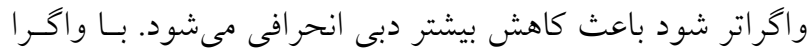

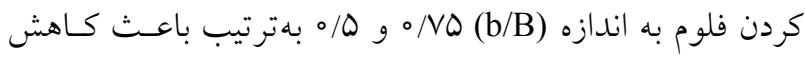

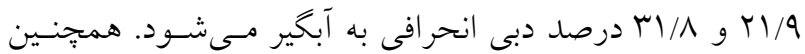

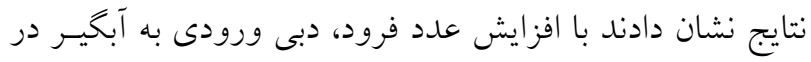

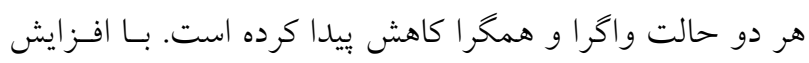

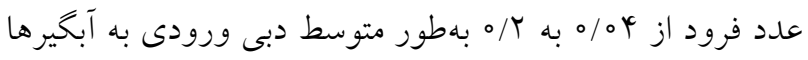
له D Dرصد كاهش ييدا كرده است. r- بر برسى اثر زاويه بر آبخير

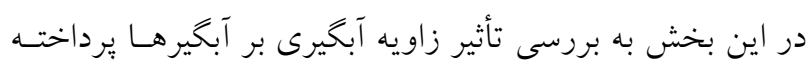
شـه است. 

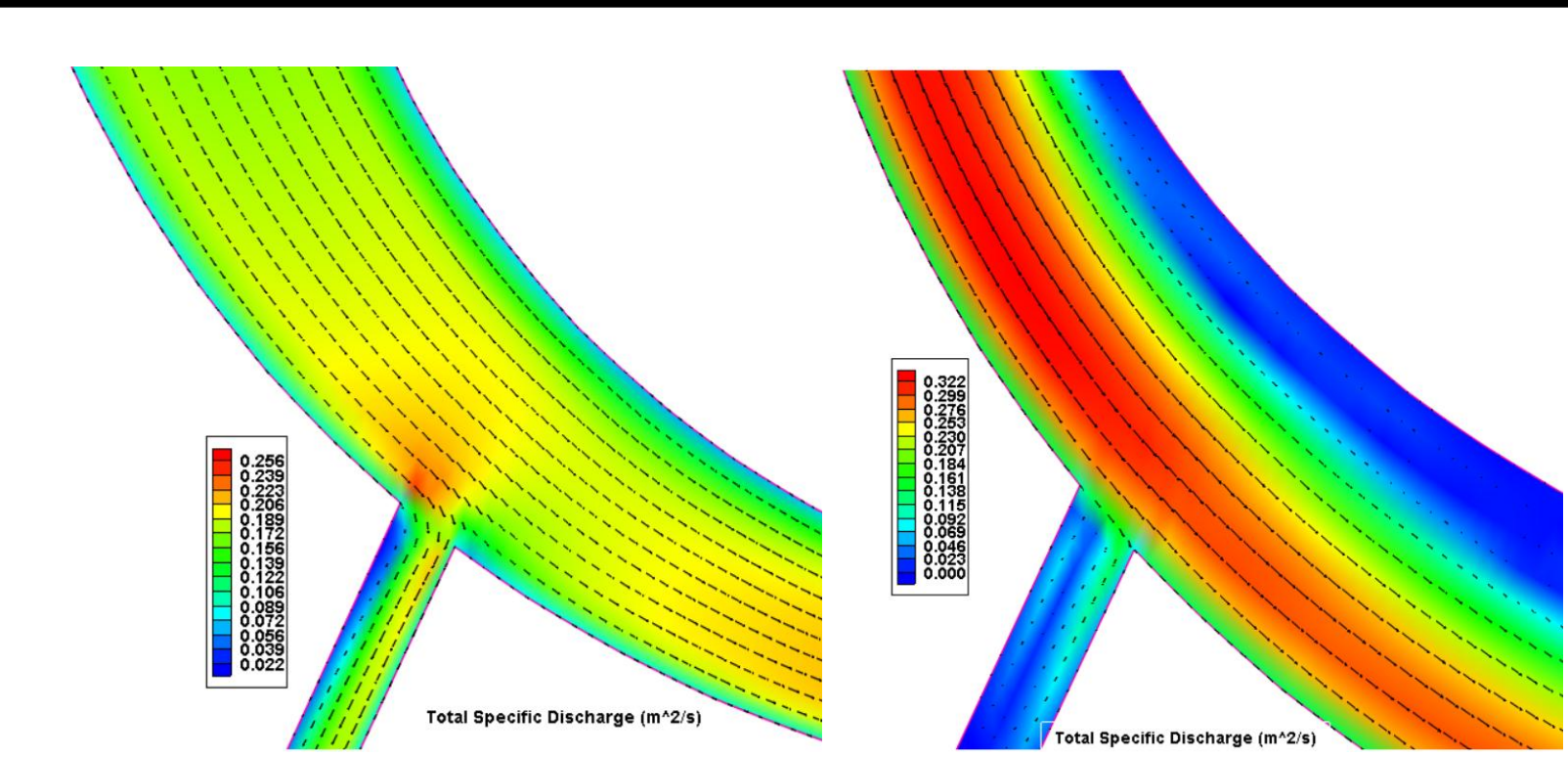

شكل rا.نتايج گر افيكى شبيهسازى آبخير در قوس همخرا و واگرا با نرمافزار CCHE2D (رنخى در نسخه الكترونيكى)

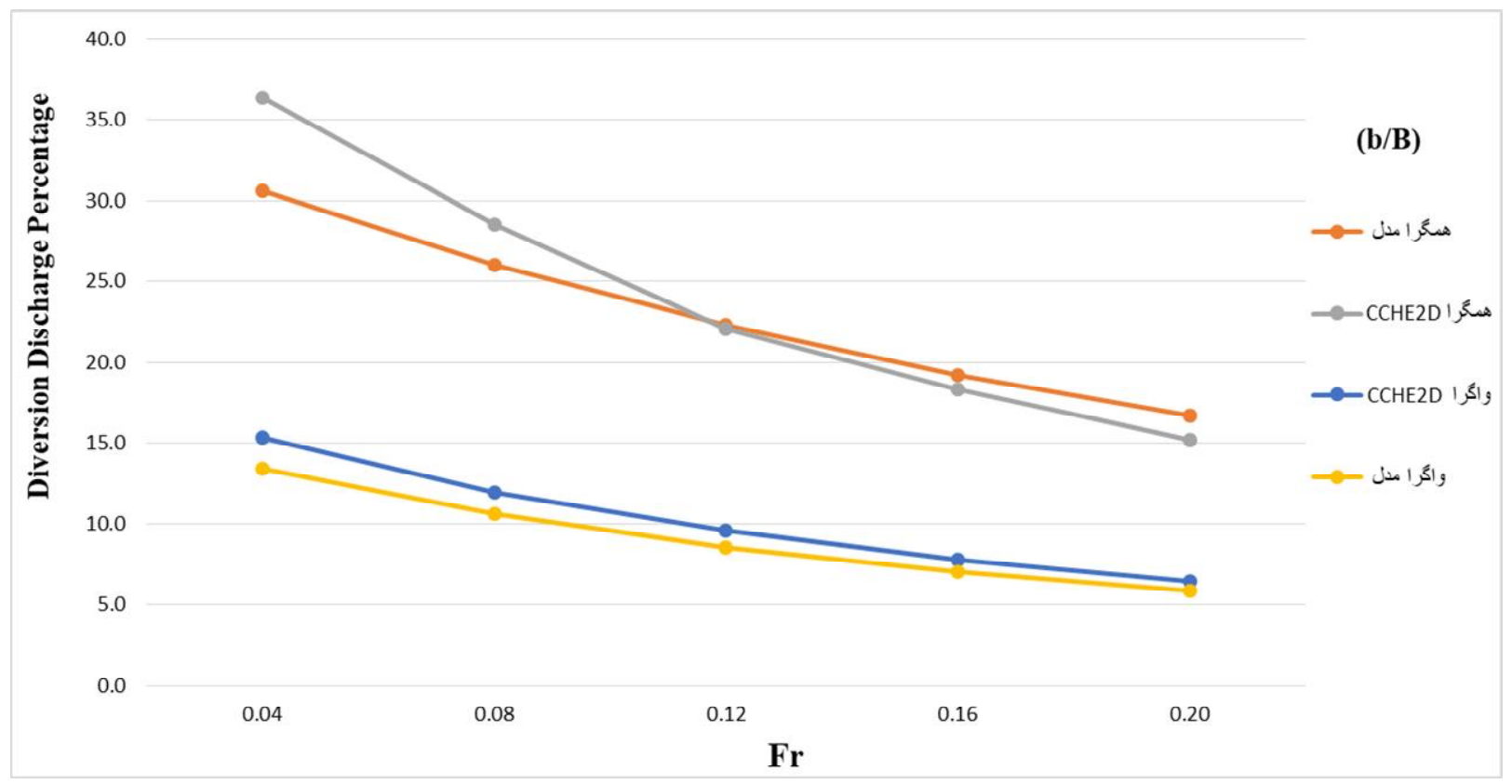

شكل با. نمودار مقايسه نتايج شبيهازى با مدل CCHE2D و مدل آزمايشخاهى (رنخى در نسخه الكترونيكى)

همخرا 4/4 درصد خطا و شبيهسازى آبخير در قوس واكرا 11/9 نتيجه گيرى

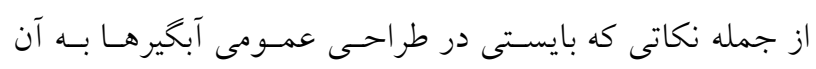

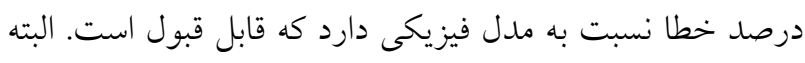

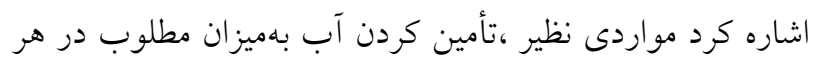

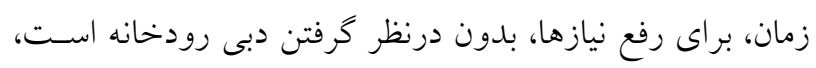

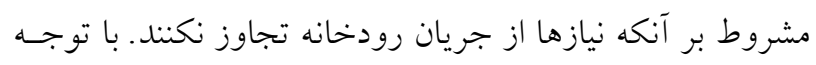

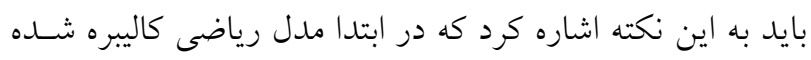
و سبس به انجام آزمايش هاى اصلى بيرداخته شد. عمـل كـاليبره باعث كم شدن خطاى شبيهسازى تا حد ممكن مى شود. 


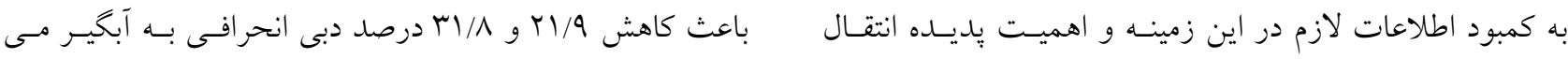

$$
\begin{aligned}
& \text { رسوب به آبخيرهاى جانبى در قوس رودخانههـا، هـدف اصدئلى } \\
& \text { r- نتايج نشان دادند با افزايش عدد فرود، دبى ورودى به آبخيـر }
\end{aligned}
$$

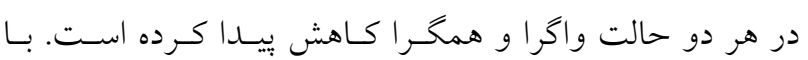

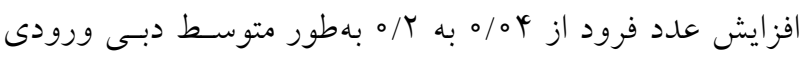

$$
\begin{aligned}
& \text { به آبخيرها }
\end{aligned}
$$

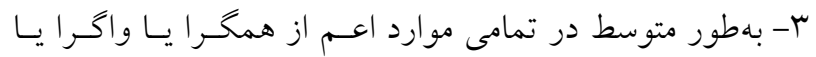

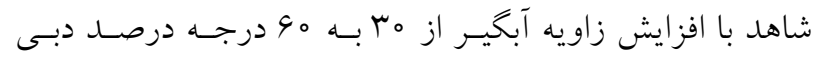

$$
\begin{aligned}
& \text { انحرافى به آبخير افزايش داشته است و در ادامه با افزايش زاويه } \\
& \text { آبخير از 09 به 09 درجه كاهش دبى آبخيرى را شـاهد هسـتيم. }
\end{aligned}
$$

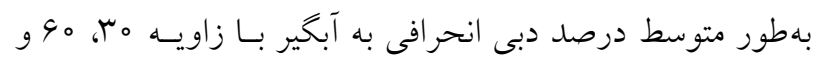

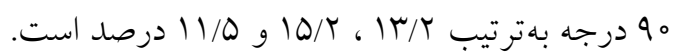

$$
\begin{aligned}
& \text { †- نتايج شبيهسازى با مدل CCHE2D نزديـك بـه نتـايج مــل } \\
& \text { فيزيكى است. شبيهسازى آبخير در قوس همخرا \/9 درصد خطا } \\
& \text { و شبيهسازى آبخير در قوس واگرا 11/9 درصد خطا نسـبت بـه } \\
& \text { مدل فيزيكى دارد كه قابل قبول است. } \\
& \text { تحقيق حاضر بر شناخت دقيق اين مكانيزم استوار اسـت. بــدين } \\
& \text { منظور با بهره كرفتن از مدل فيزيكى، اثـر تركيـب همخر ايسى و }
\end{aligned}
$$

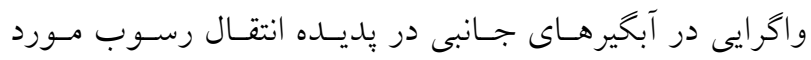

$$
\begin{aligned}
& \text { بررسى قرار خواهد گرفت. در زير خلاصه نتايج آن آمده است: } \\
& \text { ا - با همخرا كردن فلوم آزمايشـخاهى دبسى انحرافى بــه آبخيـر }
\end{aligned}
$$

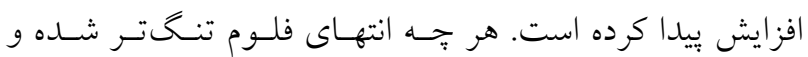

$$
\begin{aligned}
& \text { همخراتر شود باعـث افـزايش بيشـتر دبسى انحرافى مسىشـود، }
\end{aligned}
$$

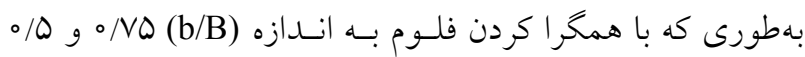

$$
\begin{aligned}
& \text { بهترتيب باعث افزايش } \\
& \text { مىشود كه مىتوان علت آن را تنخشـدكى و انســاد جريـان و } \\
& \text { هي زدن جريان به آبخير دانست. بر خلاف همخرايسى بـا واخـرا }
\end{aligned}
$$

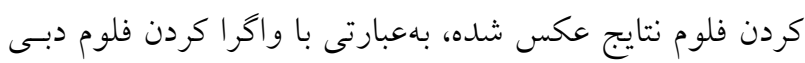

$$
\begin{aligned}
& \text { ورودىى به آبخير كاهش بيدا كرده اسـت. هـر تهـه انتهـاى فلـوم } \\
& \text { بازتر شده و واگراتر شود باعث كاهش بيشتر دبى انحرافى مسى }
\end{aligned}
$$

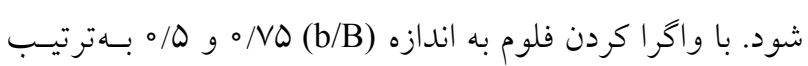

\section{منابع مورد استفاده}

1. Barkdoll, B. D., R. Ettema and A. J. Odgaard. 1999. Sediment control at lateral diversions: Limits and enhancements to vane use. Journal of Hydraulic Engineering 125(8): 862-870.

2. Biron, P. M., A. S. Ramamurthy and S. Han. 2004. Three-dimensional numerical modeling of mixing at river confluences. Journal of Hydraulic Engineering 130(3): 243-253.

3. Esmaeilnejad, M. 2002. Hydraulic laboratory study of the inlet flow to the reservoirs of Hamidiyeh diversion dam using micro model, M.Sc. Thesis of Irrigation Facilities Engineering, Shahid Chamran University of Ahvaz. (In Farsi).

4. Gravandi, E., A. Kamanbeadst, A. R. Masjedi, M. Heidarnejad and A. Bordbar. 2018. Laboratory investigation of the impact of armor dike simple and 1-shaped in upstream and downstream intake of the hydraulic flow river and intake flow rate. JWSS-Isfahan University of Technology 22(3): 55-70.

5. Hassanpour, F. and A. Ayubzadeh. 2007. The effect of submerged plates on the rate of flooding and the longitudinal profile of water level in the vicinity of 90 degree lateral reservoirs. Natural Resources 77(3): 104-110. (In Farsi).

6. Huang, J. L., L. J. Weber and G. L.Yong. 2002. Three- Dimensional Numerical study of flows in open-channel junctions flow. Journal of Hydraulic Engineering, ASCE 128(3): 268-280.

7. Hussein, A. S. A. and K. V. H. Smith. 1986. Flow and bed deviation angle in curved open channels. Journal of Hydraulic Research 23(1): 105-110.

8. Kamanbedast, A. A., S. Akib and K. Khadem. 2018. Investigation of epi structure in frontal of intakes on diversion flow in river bend with cche2d model. Feb-Fresenius Environmental Bulletin 23(12): 807-918

9. Kamanbedast, A. A., R. Nasrollahpour and M. Mashal. 2013. Estimation of sediment transport in rivers using CCHE2D model (case Study: Karkheh River). Indian Journal of Science and Technology 6(2): 4112-4115.

10. Kamanbedast, A. A. 2013. Hydraulic Structures Engineering, 1st Edition, Publication Center of Islamic Azad University of Ahvaz. (In Farsi). 
11. Khanjani, M., Gh. Barani, M. Rahmanian and M. Sajedi. 1999. Study of spatial arrangement of submerged plates to reduce sedimentary sedimentation of reservoirs with physical model. Tehran Jihad Sazandegi Research Center 15(2): 143-156.

12. Manadizadeh, M. 2013. Laboratory of hydraulic stream laboratory on the threshold of dehkhoda cultivation and industrial tank using micro model. Master's Thesis - Shushtar Islamic Azad University. (In Farsi).

13. Montaseri, H., M. Qudsian and A. Dehghani. 2009. Laboratory study of the flow field around the sunken plates in front of the lateral catchment opening in the U-shaped channel. Journal of Agricultural Sciences and Natural Resources 16(2): 175-182

14. Naghizadeh, A. and H. Behbahani. 2004. Study of hydraulic current conditions in reservoirs with a deviation angle of 90 and 75 degrees using physical model. M.Sc. Thesis in Irrigation Facilities Engineering, Shahid Chamran University Ahvaz of Ahvaz. (In Farsi).

15. Pirestani, M. and S. M. Salehi Neyshabouri. 2005. Laboratory study of the effect of hydraulic parameters on the isolated area of lateral reservoirs in arc channels. 5th Iranian Hydraulic Conference, Shahid Bahonar University of Kerman. (In Farsi).

16. Shafahi Bajestan, M. and R. Ghobadian. 2007. Hydraulic study of flow and sediment at the confluence of rivers, final report of the research project. Water Research Committee of Khuzestan Water and Power Organization. (In Farsi).

17. Shafahi Bajestan, M. and S. Nazari. 1998. The effect of reservoir deflection angle on the amount of sediment entering the lateral reservoirs in the vertical bend of the river. Journal of Agricultural Science, Shahid Chamran University of Ahvaz 22(3): 93-108. (In Farsi).

18. Zahiri, J. and M. Kashefipour. 2009. Study of the effect of various factors on the amount of sediment entering the lateral reservoir using bilateral variance analysis. 8th International Seminar on River Engineering, Shahid Chamran University. (In Farsi).

19. Zahiri, J. and M. Ashnavar. 2019. Two dimensional hydraulic modeling of Karun river. JWSS-Isfahan University of Technology 23(4) :331-344. 


\title{
The Effect of Convergence and Divergence on Flow Pattern and Sediment Transport in Lateral Intakes
}

\author{
P. Heydari Rad ${ }^{1}$, A. A. Kamanbedast ${ }^{1 *}$, M. Heidarnejad ${ }^{1}$, A. R. Masjedi ${ }^{1}$ \\ and $\mathrm{H}$. Hasoonizadeh ${ }^{2}$
}

(Received: April 3-2018; Accepted: October 6-2018)

\begin{abstract}
Water supply at a desired rate at any time to meet the water requirements regardless of river discharge must be considered in the general design of intakes provided that the needs do not exceed the river flow. Due to the lack of necessary information in this field and the importance of sediment transport to the lateral intakes at river bends, this study aimed at understanding the mechanism of this phenomenon. To this end, the combined effect of convergence and divergence in lateral intakes on the sediment transport was investigated. According to the results, the diversion discharge to the intake was increased by converging the laboratory flume. By narrowing and converging the end of the flume, the diversion discharge was increased further, so that as the flume was converged to the size (b/B) of 0.75 and 0.5 , the diversion discharge to the intake was increased by $13.6 \%$ and $75 \%$, respectively. This could be connected to narrowing, flow obstruction and backflow to the intake. In contrast, different results were found by diverging the flume. In other words, the inflow to the intake was decreased by diverging the flume. As the flume end was diverged, the diversion discharge was decreased further. By diverging the flume to the size (b/B) of 0.75 and 0.5 , the diversion discharge to the intake was decreased by 21.9 and $31.8 \%$, respectively. The average diversion discharge to the intake at 30,60 and $90^{\circ}$ was $13.2,15.2$ and $11.5 \%$, respectively. By converting the flume to the size (b/B) of 0.75 and 0.5 , the diversion sediment to the intake was increased by 18.5 and $71.4 \%$. In contrast, by diverging the flume to the size (b/B) of 0.75 and 0.5 , the diversion sediment to the intake was decreased by 35.4 and $49.9 \%$, respectively.
\end{abstract}

Keywords: Intake, Sediment transport, Divergence, Convergence, Diversion discharge

1- Department of Water Science and Engineering, Ahvaz Branch, Islamic Azad University, Ahvaz, Iran.

2- Khouzestan Water and Power Authorithy.

*: Corresponding author, Email: Ka57_amir@yahoo.com 